\title{
DIABLO wt Allele
}

National Cancer Institute

\section{Source}

National Cancer Institute. DIABLO wt Allele. NCI Thesaurus. Code C105652.

Human DIABLO wild-type allele is located in the vicinity of 12q24.31 and is approximately $20 \mathrm{~kb}$ in length. This allele, which encodes diablo homolog, mitochondrial protein, is involved in the promotion of caspase-mediated apoptosis. Mutation of the gene is associated with deafness autosomal dominant type 64 . 